\title{
The study of lithic assemblages on deflation surfaces: The case study of Arroyo Verde, Northern Patagonia coast, Argentina
}

\author{
Eugenia Carranza \\ Instituto Multidisciplinario de Historia y Ciencias Humanas (IMHICIHU - CONICET). Saavedra 15, 5th floor, \\ (C1083ACA), Buenos Aires, Argentina. Email: carranza.e89@gmail.com
}

\begin{abstract}
:
This paper focuses on surface lithic artefacts from Holocene coastal hunter gatherer occupations of Arroyo Verde archaeological locality (Rio Negro province, Northern Patagonia, Argentina). The study of lithic assemblages collected at a deflation surface surrounded by stabilised sand dunes near the coastline, shows that wind produce significant corrasion (wind abrasion) of artefacts and affects preservation of small and medium size artefacts. The sample is mainly composed of chert knapping debitage with abraded and polished edges and surfaces. The artefact size distribution suggests that a subset of the assemblage exhibits good preservation, possibly due to the recent subaerial exposure. Furthermore, carbonate and mould coatings were recorded over the artefacts surface in contact with the ground, which indicates the presence of humid conditions in the sand dunes deflation area. In order to explore the factors that affected assemblage stability conditions in the locus, a machine learning based decision tree was applied. The model predicts and defines a threshold at which the occurrence of instability conditions may appear. Also, it suggests that relative altitude of artefacts within the deflation hollow is the primary variable explaining the exposure conditions recorded in the artefacts and it points out processes of differential deflation over time. The data presented here illustrates how wind alters local surface materials and emphasizes that a taphonomic perspective is needed to assess the formation processes within northern Patagonia coastal archaeological assemblages.
\end{abstract}

Keywords: surface lithic scatter; Aeolian environment; taphonomy; formation processes; northern Patagonia

\section{Introduction}

Coastal regions are among the most affected environments by the strong energy of the wind (Bullard 2006; Butzer 2004; Lancaster 1998; Livingstone \& Warren 1996; Mayer 2002; Rick 2002; Waters 1992). The Patagonian coast of Argentina is subject to strong winds from the SW that erode, transport and redeposits sediments, causing geomorphological processes that continuously shape the landscape. It also affects the archaeological record, that it is why assessing the role of the wind in the formation and preservation of archaeological sites is very

Published by the School of History, Classics and Archaeology, University of Edinburgh ISSN: 2055-0472. URL: http://journals.ed.ac.uk/lithicstudies/ 
important to understand human past behaviour (Borrazzo 2006; 2013; Borrazzo \& Borrero 2015; Borrero 2001; Cruz et al. 2015; Leonardt et al. 2016).

Within the Northern Patagonia coast, the San Matias Gulf (Figure 1) is a semi-arid region with records for human occupations dated to the middle Holocene (Favier Dubois et al. 2008). The study of the evolution of sand dunes and aeolian deposits is important at the local as well as the regional scale because it allows assessing the spatial and temporal properties of the coastal archaeological record. These landforms were frequently selected for human burials (Bonomo et al. 2017; Favier Dubois et al. 2008) and as shelters from the strong winds (Favier Dubois \& Borella 2011). Also, the dunes concentrate groundwater, thus offering an important source of fresh water within a semi-arid environment. The archaeological localities known in the San Matías Gulf are frequently located in aeolian deposits developed on marine terraces or on landforms of fluvial origin (Favier Dubois \& Kokot 2011). The archaeological record is found in deposits like shell middens and on the surface across the landscape (Manzi et al. 2011). Two of the main formation processes in that region are deflation and abrasion by wind action. These processes modify the archaeological deposits by exposing materials to differential weathering and mixing artefacts from several depositional events, and thus generating temporal palimpsests (Bailey 2007; Davies et al. 2016; Fanning et al. 2009; Favier Dubois \& Borella 2007; Favier Dubois et al. 2008).

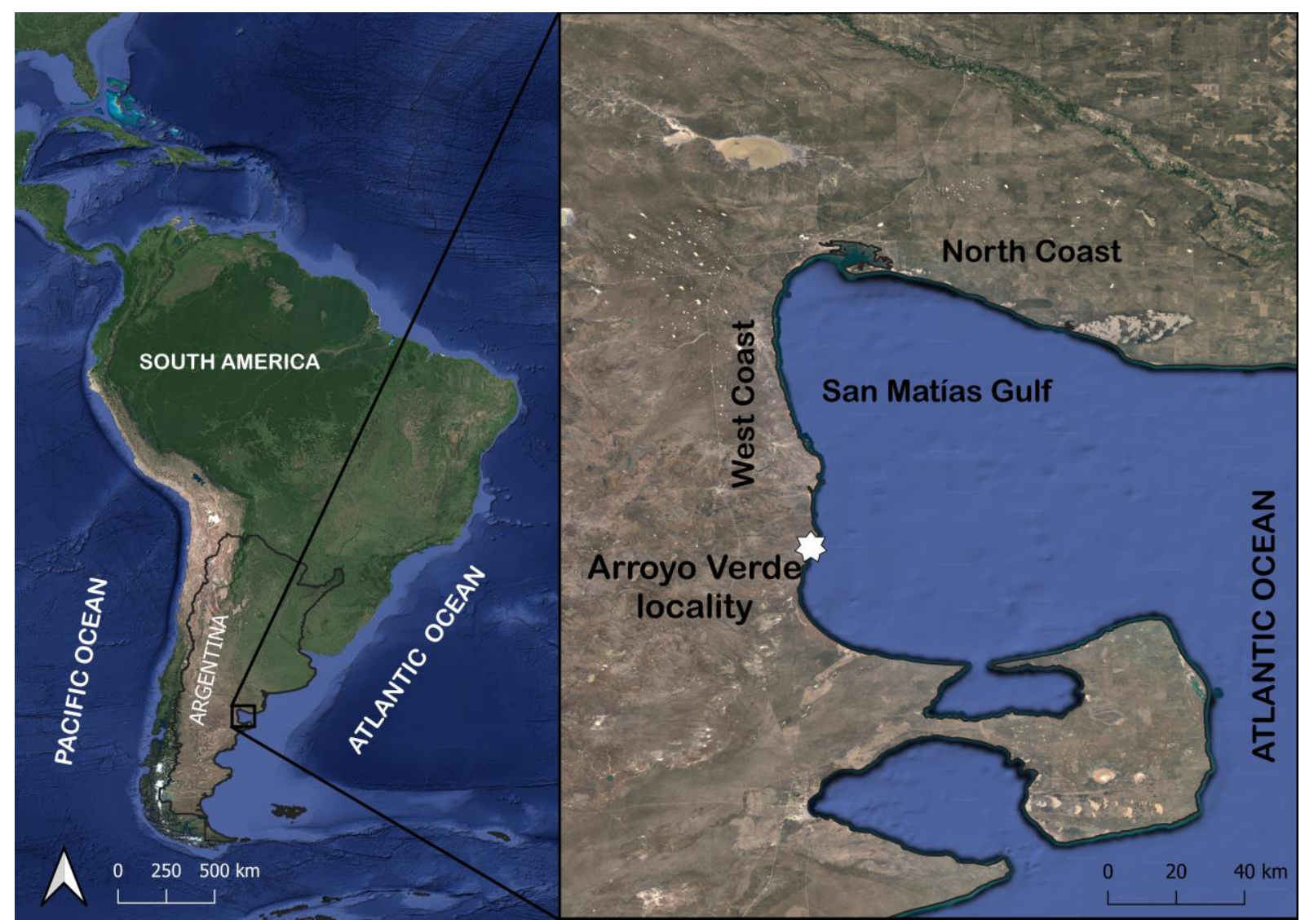

Figure 1. Location of the study area.

On the West coast of San Matias Gulf dunes are scarce and less ubiquitous than on the northern coast due to its geological and environmental characteristics (Favier Dubois \& Borella 2011). The Arroyo Verde locality is an exception to this general pattern, since it is an active dune field covering $120,291 \mathrm{~m}^{2}$. These aeolian sand dunes contain the archaeological material product of human occupations that took place in a dune setting or ancient marine terraces which are covered by aeolian sediments (Mayer 2002). Due to wind erosion, and the 
deflation processes it causes, the archaeological record was alternatively buried and exposed (Cameron et al. 1990; Fanning \& Holdaway 2001; Favier Dubois et al. 2008). Previous work in the area indicated the presence of a blowout dune, a collapsed dune profile and surface scatters (Gómez Otero 2006). In subsequent visits to the location (years 2016 and 2017), we observed the same features that were reported 10 years before, as well as records of continuous intense wind erosion.

The aim of this paper is to evaluate the effects of wind on the lithic archaeological record in the Playón locus of the Arroyo Verde locality. We will present a taphonomic characterisation of the lithic scatters through statistical and descriptive methods. We will also assess wind morphological and distributional taphonomic effects over artefact attributes and identify the post-depositional geomorphic processes that probably affected the context. Finally, this study will provide new insights to improve the understanding of the regional depositional histories.

\subsection{Study area}

The North and West coasts of the San Matías Gulf have diverse geological and geomorphological features that gave it different land use strategies by the hunters-gatherers who occupied the area during the middle and late Holocene. In addition, both coasts exhibit differences in the way in which the archaeological assemblages are found today and display variation in their degrees of preservation (Favier Dubois \& Borella 2011). The region is characterised by an arid-semiarid climate, with mean temperature of $15^{\circ} \mathrm{C}$, annual rainfall below $300 \mathrm{~mm}$ and a low-lying shrub vegetation, monte, dominated by Larrea sp. (Cabrera \& Willink 1973). Tides are semidiurnal and have a macro tidal regime, with means amplitudes of $6 \mathrm{~m}$ and a maximum value of $9 \mathrm{~m}$, recorded at the Bahía San Antonio (Servicio de Hidrografía Naval 2009). The direction of the wind is predominantly west and reaches a maximum average speed of $23.6 \mathrm{~km} / \mathrm{h}$ (Servicio Meteorológico Nacional 2014).

The West coast presents faulty and folded igneous and metamorphic rocks (González Díaz \& Malagnino 1984). It has more homogeneous environments and lesser biodiversity of marine species (Favier Dubois \& Borella 2011; Favier Dubois et al. 2008). In addition, fresh water is scarce because of the low development of water pools, known as aguadas, which are associated with wind deposits. In some sectors of this coast, there are small estuaries or bays with sandy beaches, very prone to preserve stratigraphic archaeological contexts (Favier Dubois et al. 2016). Surface materials were found on Aeolian mantles and within small shell middens - exhibiting different degrees of preservation (Borella et al. 2015; Favier Dubois et al. 2016). Previous work proposed that the West coast of San Matias Gulf was a corridor with low intensity occupations (Borella et al. 2015; Favier Dubois \& Borella 2011). Indeed, the archaeological record is scarce; thus, it was suggested a sporadic, not redundant use of the space. Among the exceptions to this general pattern is Arroyo Verde locality, which exhibits an abundant archaeological record (Borella et al. 2015).

The Arroyo Verde locality is $c a .3 .4 \mathrm{~km}$ to the north of the Verde spring and at $100 \mathrm{~m}$ from the sea (Figure 1). Different environments converge in the locality, like sandy beaches, dunes and the mouth of the Verde creek (an ephemeral and seasonal source of freshwater), between Holocene and Pleistocene marine terraces. The locality is an extensive blowout surrounded by vegetated dunes. The older chronology for the locality was obtained from a shell midden dated $7000{ }^{14} \mathrm{C}$ yr BP (Gómez Otero 2006). More recently, two dates of 3000 ${ }^{14} \mathrm{C}$ yr BP from one shell midden, and $5500{ }^{14} \mathrm{C}$ yr. BP from a paleo-beach deposit on a marine terrace were added (Favier Dubois et al. 2017). Although the space would have been available from that time, the oldest date for human occupations is still a topic under discussion (Favier Dubois et al. 2017). 
Gómez Otero (2006) characterised the locality as an energy capture locus with evidence of expedient technological behaviour. Also, the author considered that the dunes were primarily selected for human settlement because the interdune areas offer shelter from climatic conditions. According to different lines of evidence, the deflation surfaces, which register the highest concentrations of artefacts in the area, would have formed after human occupations.

Vegetated sand dunes are located along the Rio Negro Province maritime coast and the archaeological materials within Aeolian deposits mostly evidence the action of paedological processes (e.g., root marks, rhizoconcretions, bones and artefacts with carbonate coating). These paedological processes were favoured or inhibited by palaeoclimatic fluctuations. During fieldwork rhizoconcretions (small cylindrical concretions composed of calcium carbonate and quartz sand) were recorded in the Arroyo Verde locality, which are indicators of recent deflation. Also, in the sampled area we observed the presence of a pebble ridge perpendicular to the sea, which may show an old position of the coastline. We observed guanaco (Lama guanicoe) dung piles and wallows all along the sampling area. There are guanaco groups and vehicles touring the area and leaving their traces. The tracks run through the entire dune sector and trigger erosive processes (Manzi et al. 2009) (Figure 2). At present, deflation reaches an unprecedented scale mainly because of the anthropogenic impact (Favier Dubois et al. 2008; Manzi et al. 2009), and hence this landscape is subjected to a general degradation condition (Favier Dubois et al. 2016).

\section{Materials and methods}

The Playón locus is a sparsely vegetated deflation or blowout surface, with hollows excavated by onshore winds, with sand driven mainly landward to form a looped ridge (Bird 2011). During fieldwork, the total collection of findings was made in an area of $3,500 \mathrm{~m}^{2}$ (Figure 3). A GPS was used to take the relative position and height of each specimen to map its distribution in the sampling unit. All the measurements were taken with the same GPS during the same day, so the GPS error is a constant in our study and only relative measurements were performed with these data.

In the laboratory, we undertook the techno-morphological (sensu Aschero 1975-1983) and the taphonomic (sensu Borrazzo 2006) analyses of the whole lithic assemblage. The latter analysis includes the assessment of morphological and distributional taphonomic effects. The morphological taphonomic effects are those that refer to the post-depositional modifications suffered by the artefacts that imply changes in their formal attributes (Borrazzo 2016). Wind abrasion (corrasion) (Breed et al. 1997) and its intensity (Borrazzo 2006) were recorded to study morphological effects. Regarding the variables selected, it is worth mentioning that corrasion - the polishing of the edges and surface of the pieces due to the impact of the particles transported by wind is the main alteration registered on lithics in the study area. The intensity with which this phenomenon modifies the lithic surface depends on both exposure duration and the physical-mechanical properties of artefact raw materials (homogeneity, hardness, cohesion, and grain size) (Breed et al. 1997; Camuffo 1995). Therefore, this taphonomic effect is an unambiguous marker of air exposure useful to discuss differential subaerial exposure time within lithic assemblages (Borrazzo 2006). This alteration has been categorised (sensu Borrazzo 2006) in four stages: a) 0 or fresh: it records no corrasion, the surface has the same appearance as the interior of the rock; b) 1 or soft corrasion: rock keeps its original texture and is slightly abraded; c) 2 or corrasion: the surface and edges of the artefact are polished and shine; and d) 3 or strong corrasion: the whole artefact is abraded, its edges are completely rounded. These categories were recorded macroscopically. 

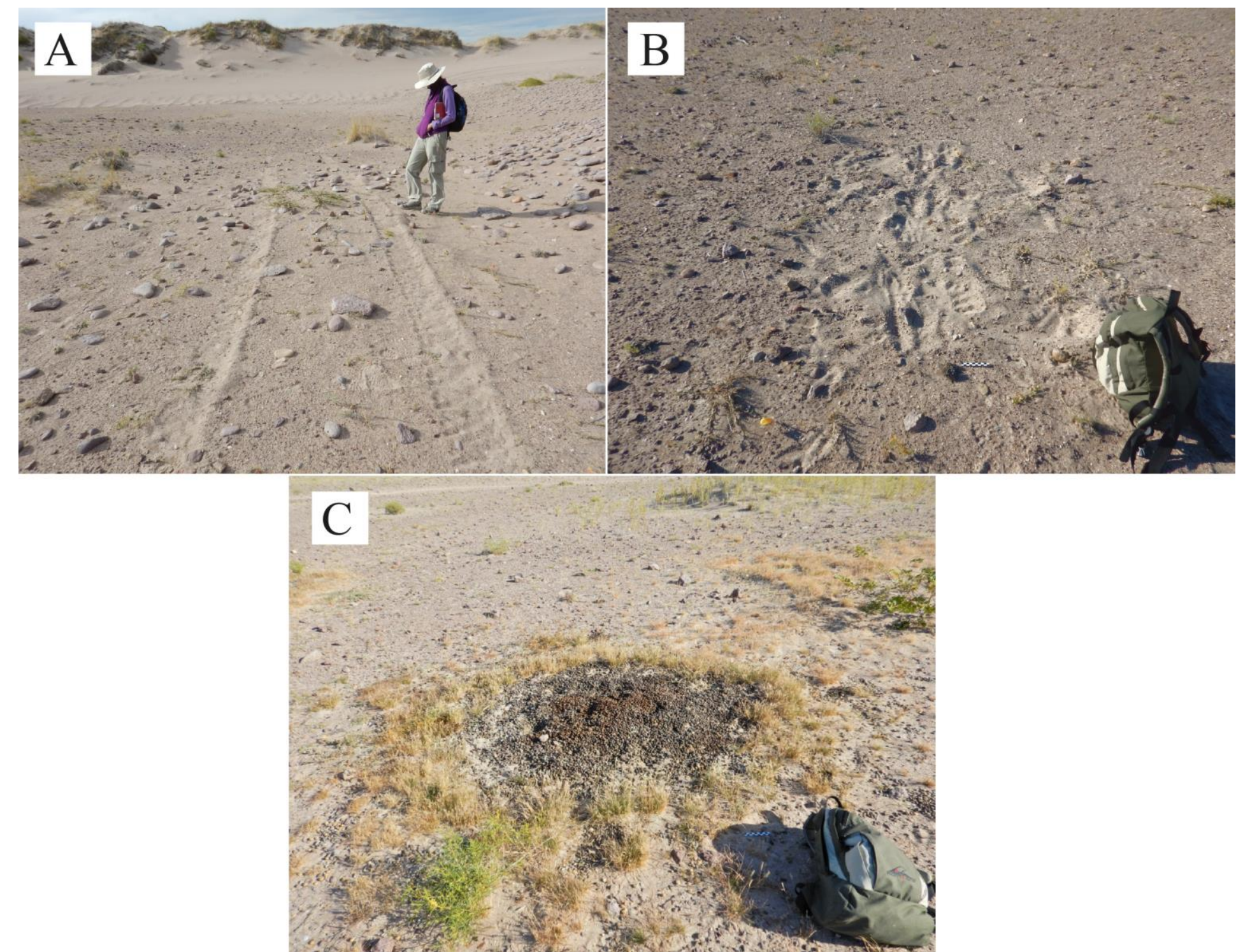

Figure 2. A) Vehicles tracks through the dune sector; B and C) guanaco's dung piles and tracks. 

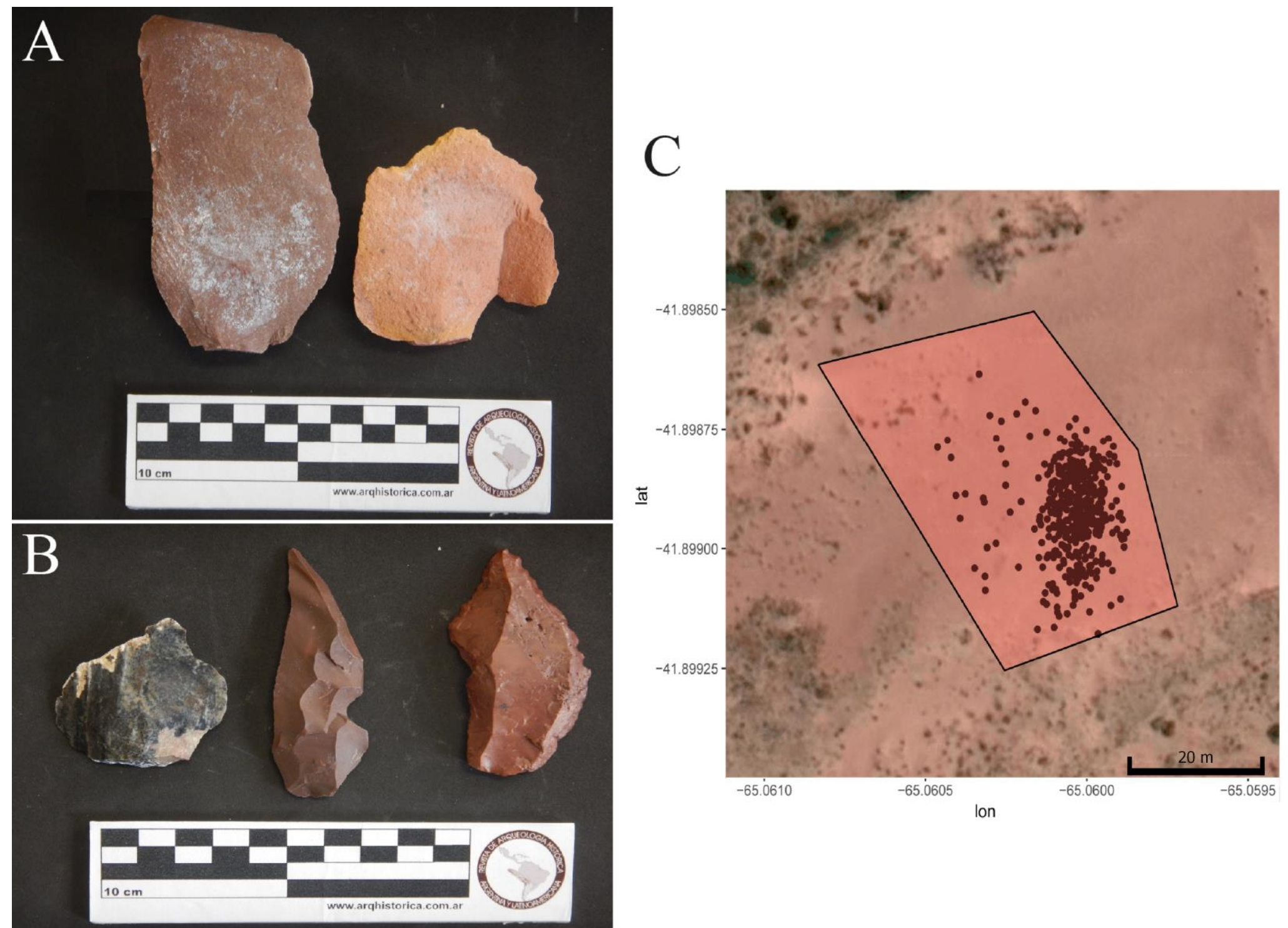

Figure 3. Artefacts collected with A) carbonate coating and B) soft corrasion surface. C) Sampling area and the distribution of specimens analysed herein. 
Carbonation (coating or rock coating) was recorded on the artefact's surface. This is a deposit of accretionary minerals - mainly carbonates - of varying thickness, which alters the appearance of the artefact surface (Dorn 2009). In this study, the area covered by the rock coating was recorded using $5 \%$ intervals.

Altogether, the phenomena recorded were used to characterise the stability of artefacts. The record of stability results from the differential presence of taphonomic indicators of exposure on the surface of any specimen (Borrero 2007). To test the occurrence of changes in the position of the pieces throughout their post-depositional life, the location and extension of corrasion and carbonation were analysed on each artefact surface, i.e., dorsal and ventral (Borrazzo 2006; Borrero 2007; Gifford 1981).

The spatial taphonomic effects or transformations are changes in the artefact distribution, such as its displacement (i.e., vertical and horizontal) and rotation. Particle size sorting (i.e., artefact granulometry) is one by-product of the spatial taphonomic effects (Borrazzo 2016). Differences in the size distributions within the blowout are expected because of the sorting action of the wind (Baker 1978; Borrazzo 2006; Lancaster 1986); for example, it is expected the predominance of artefacts of larger sizes and weights because of the deflation of fine and light particles. To assess the effects or spatial transformations (sensu Borrazzo 2016; 2018) induced by wind, the weight of each piece was recorded. Subsequently, weight data was used for modelling sample composition and granulometry.

\subsection{Statistical methods}

A decision tree analysis was performed with Fast and Frugal Tree searching algorithms (FFT) (Phillips et al. 2017) to explore the factors that conditioned assemblage stability. Decision tree methods are powerful machine learning algorithms to establish classification parameters based on a set of categorical or continuous independent variables over an input categorical variable (i.e., CART, C50, Random Forest, Fast and Frugal Trees). The pioneer application of Weitzel et al. (2014) also showed that these methods can be useful in lithic taphonomy and geoarchaeological research to predict a binary outcome (i.e., lithic artefact fracture probability). The structure of the decision tree can be described from its nodes and its branches (Song \& Ying 2015). The nodes contain 'the decision' and originate from a main node or root which it expresses the most important variable. Only one decision (in this case stable-instable) is possible in the root and in the intermediate nodes, while in the last one it expressed both decisions together. The branches represent chance outcomes or occurrences that emanate from root nodes and internal nodes. A decision tree model uses a hierarchy of branches. Each path from the root node through internal nodes to a leaf node represents a classification decision rule (Song \& Ying 2015).

Fast and Frugal Trees (FFT) are one special kind of decision trees, which are basically supervised learning algorithms created to predict a binary criterion based on a set of predictor values, also called "cues" in this context. The FFT main goal is not only the description of existing data but rather the prediction of new information. The generated model is expected to explain with the minimum possible error the differences in stability observed in the blowout. The larger the sample destined to the training phase of the tree, the less variability in the prediction phase. Small samples will generate more variable trees. Here, $80 \%(n=373)$ of the sample is assigned for training purpose and the remaining $20 \%(\mathrm{n}=72)$ is used for testing the model. The comparison between the first (training) and the second model (testing), will also serve as a measure of the FFT effectiveness in this study. Relative fitting success can be measured from an error matrix also known as a confusion matrix. Each row of the matrix represents the predicted results count vs. the observed values for the dependent variable. As the answer is dichotomous, the correct prediction is called sensitivity (hit rate), whereas the 
correct rejection is called specificity (rejection rate). The most efficient model will be the one that can predict the state of the dependent variable with the least error. It defines sensitivity as sens $=\mathrm{hi} /(\mathrm{hi}+\mathrm{mi})(\mathrm{hi}=$ hit rate, $\mathrm{mi}=$ misses $)$ and represents the percentage of cases with positive criterion values that the algorithm correctly predicted. Similarly, it defines specificity as $\mathrm{spec}=\mathrm{cr} /(\mathrm{fa}+\mathrm{cr})(\mathrm{fa}=$ false alarm, $\mathrm{cr}=$ correct rejections $)$ and represents the percentage of cases with negative criterion values correctly predicted by the algorithm. Also, the balance accuracy (bacc) was considered, and the relation between both sensitivity and specificity was estimated as sens $\times w+e s p \times w$ (where $w$ is the weight and varies between 0 and 1). For this study, the default value of 0.5 (it gives the same weight to both measures) was chosen.

As it was explained above, a set of different variables was measured during the data collection. However, since generating the simplest model as possible was the primary goal of the present study, variables that explain a marginal amount of the total variance in relation to the binary outcome were left out for decision tree reconstruction.

\section{Data results}

\subsection{Techno morphological analysis}

The assemblage analysed consists of 445 lithic artefacts, $405(91 \%)$ of which are flakes and debris. The rest of the assemblage corresponds to 29 cores $(6.5 \%)$ and 7 tools $(2.4 \%)$. Tools are unifacial, like denticulates and endscrapers. Chert is the most represented raw material in the assemblage ( $\mathrm{n}=226 ; 68.2 \%$ ), followed by chalcedony ( $\mathrm{n}=105 ; 31.7 \%)$, both of very good flaking quality and available in local lithic sources.

\subsection{Morphological taphonomic effects}

The corrasion stages 1 (soft corrasion) and 2 (corrasion) presented similar frequencies (35.2\% and $34.9 \%$, respectively). Both categories were recorded mainly on the artefact surface exposed to wind at the time of collection. $15.8 \%$ of the sample registered stage 3 (strong corrasion). Finally, only $0.14 \%$ of the total sample recorded stage 0 (fresh). These results show that over $99 \%$ of the lithic artefacts analysed exhibit evidence of subaerial exposure and ca. 50\% of the cases have strong Aeolian abrasion (stage 2 and 3).

Carbonate was recorded on $5.2 \%$ of the sample. This coating was generally found on artefact surface in contact with the substrate at the time of collection (Alberti \& Carranza 2014). This coating is primarily present on the edges of the specimens (i.e., retouch scars and platform). The artefacts with carbonate coating were distributed at an average height of 6.95 $\mathrm{m}$ and their presence decreases toward higher heights. Other than this rock coating, 55 pieces show a green adherence (mould or moss) on their surface in contact with the ground and they were distributed at an average height of $7.10 \mathrm{~m}$. The occurrence of both alterations at similar relative average height suggests that the humid conditions were related to the presence of a body of water and the recent flooding and erosion of the soil.

The stability conditions of the lithic artefacts were assessed using the location, extension, and intensity of the morphological effects (i.e., corrasion, carbonates, mould). As it was explained above, stability conditions can be evaluated from the differential presence and distribution of taphonomic indicators on a lithic piece. The results yielded conditions of greater stability for those artefacts with stages 2 and 3. While the less stable conditions (i.e. higher frequency of movements) were recorded among the artefacts with corrasion in stage 1. These results suggest that pieces with lesser subaerial exposure show lesser stable conditions, while those with longer exposure time and stronger stages of corrasion, mostly record stable conditions. The records of stability in the sample considering all variables was analysed using statistical methods (see section 3.4). 


\subsection{Distributional taphonomic effects}

To test the distribution of artefact sizes, the weight of the whole sample (445 pieces) was considered. Artefact weight provides a proxy for artefact size. We expect that smaller pieces to move more frequently in coastal dune contexts because the wind acts as a selective agent (Baker 1978; Borrazzo 2016; Lancaster 1986). The heavier pieces (and therefore larger size) have more chances to remain in their position when subject to wind action. The weight values recorded within the sample have a minimum of $0.4 \mathrm{~g}$ and a maximum of $343 \mathrm{~g}$ and the average is $17.65 \mathrm{~g}$. These values suggest an approximately normal distribution of weight, with the presence of small pieces. This information allows us to limit the range of sizes present in the locus and discuss its relevance in terms of preservation and integrity (Bertran et al. 2012).

When mapping the pieces in the space surveyed, it is observed that they concentrate on the lowest portion of the deflation basin (i.e., depression) (Figure 4). This may be informing about the dynamics of the pieces within the landform, departing from the dune eroded profile towards the centre of the basin due to gravity, and generates differential expectations about the stability conditions for artefacts recovered from different segments of the deflation basin (see Discussion).

\subsection{Statistical results}

Statistical modelling suggests that the stable conditions are primarily a result of the altitude at which the piece was recovered and its weight (Figure 5). The model predicts the occurrence of stable conditions for altitudes with values greater than $8 \mathrm{~m}$. In addition, pieces that weight less than $3 \mathrm{~g}$ would have been less stable than those with values above this threshold. For the model adjustment phase, a random sample of $80 \%$ of the sample was used, and validation was carried out with the remaining $20 \%$ of the sample. The $28 \%$ of the latter exhibits more stable conditions and $72 \%$ shows non-stable conditions.

The final model has adjustment rates of $30 \%$ specificity, which measures the positive observations (no stability) and when the absence of change or stability occurs. While the sensitivity rate (null observations - stability) is $94 \%$ showing to what extent the model detects the conditions that cause instability.

The average value for acc and bacc is $76 \%$ and $62 \%$ respectively, which shows an overall average precision. This index balances sensitivity and specificity and in this case, the model is efficient in predicting less stable cases (with $77 \%$ correct answers). However, it is not very efficient in determining which cases should present stable conditions. The latter may be due to several factors we discuss below (see Discussion). 


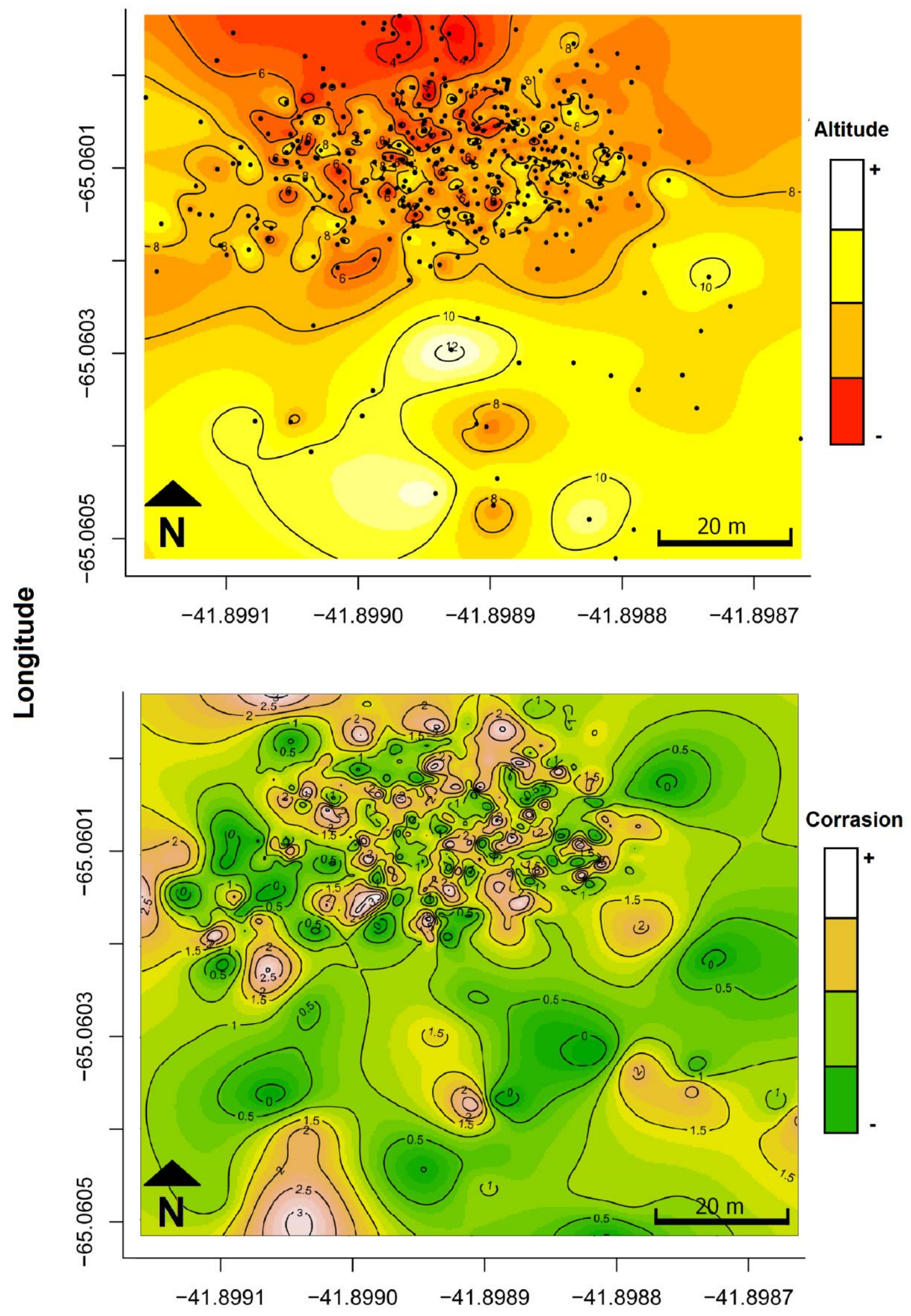

\section{Latitude}

Figure 4. Distribution of artefacts in relation to recorded altitude and corrasion into the sampling area. 


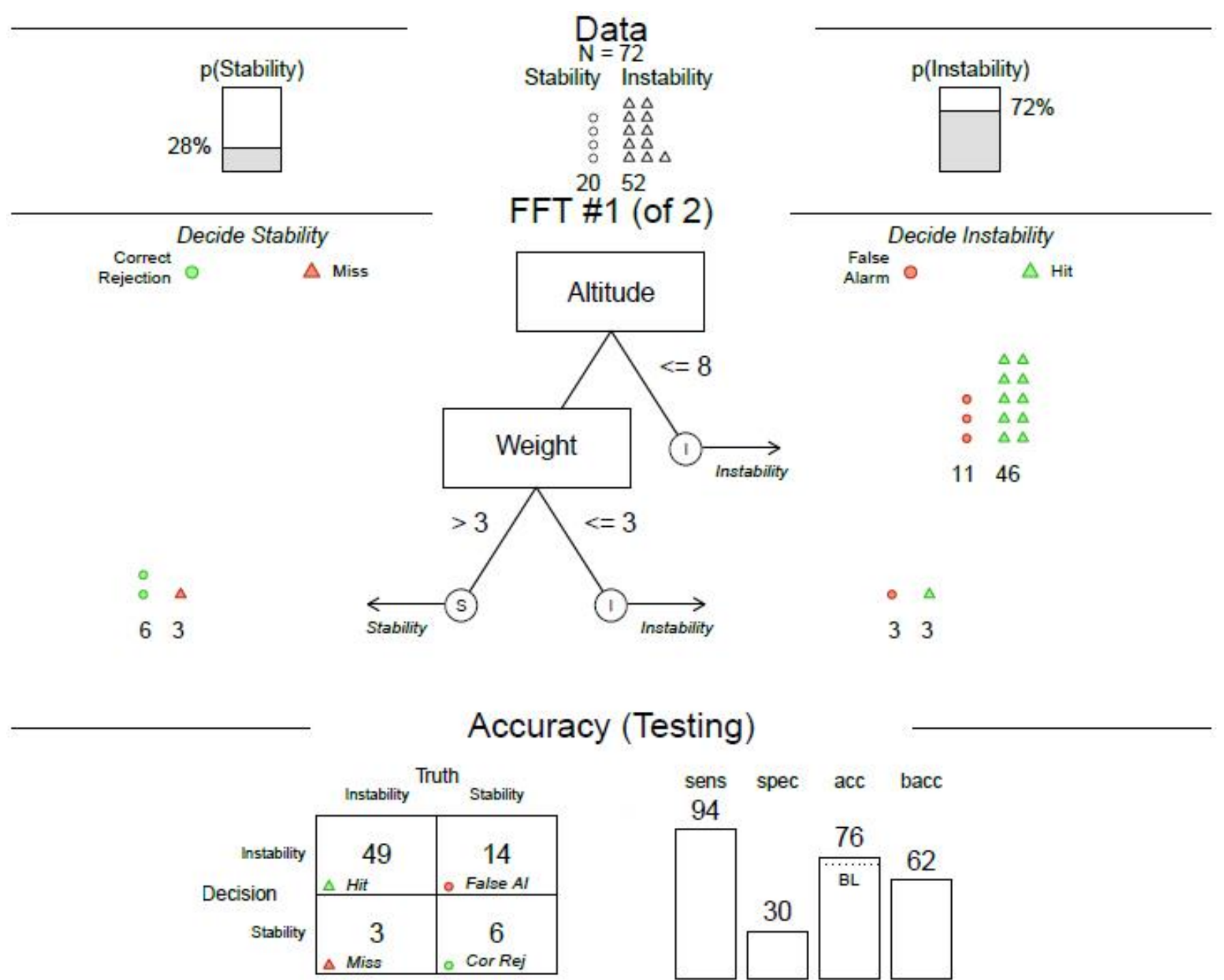

Figure 5. Best tree (upper centre) and performance statistics (bottom) for a testing phase using the remaining $30 \%$ of the sample $(\mathrm{n}=72)$. At the bottom, fitting values of the tree model. Abbreviations: sens: sensibility, spec: specificity, acc: accuracy, bacc: balance accuracy. 


\section{Interpretation of the data}

The results of this study suggest that the lithic assemblages of the blowout were exposed on the surface to the wind and its sediment load was long enough for this process to (i.e., taphonomic effect). Effectively, corrasion is present on more than $99 \%$ of the artefacts. This trend may show the continuity of erosion processes in this area. Stages 1 and 2 of corrasion exhibit the higher frequencies in the sample, while a lower presence of extreme stages - 0 and 3 - was recorded. The scarce presence of carbonate coatings on the surface of the artefacts shows the lack of adequate conditions for these phenomena to develop and preserve. Therefore, it may not be a very informative variable in this context. Its low frequency is related to subaerial exposure since sediment impacts remove the crust from the artefact and prevents their development on the exposed surface. As mentioned, we register their presence mainly on the artefact surface in contact with the ground. Along with the pieces with carbonate, artefacts with green organic adhesions (moss) were also recorded. Both phenomena are observed on materials that were recovered from the lower relative heights of the sampling area, and thus were already incorporated into the bottom of the blowout. This suggests the availability of water bodies or at least the existence of more humid condition at the bottom of the blowout. Borrazzo and Borrero (2015) recorded a similar trend in the coastal sand dunes of Tierra del Fuego (Argentina).

The results of the stability analysis suggest that the more stable conditions are recorded on pieces averaging longer exposure times that are located in the lower part of the basin. The pieces that recorded stages 2 and 3 of corrasion show the most stable conditions of the assemblage and they are located in the blowout's bottom, while the less stable conditions were recorded on pieces with stage 1 of corrasion. These pieces are located in the higher areas within the blowout; they would have been recently uncovered (exposed) and still subjected to cycles of exposure-erosion into the deflated surface towards the blowout bottom. The corrasion stages recorded on the lithic material and their differential distribution in space may account for burial cycles of remains within the sand dunes and the variable exposure time as pieces accumulate and stabilize in the blowout bottom. Therefore, the conditions within the deflation surface seem to be variable at Playón locus of Arroyo Verde. So far, the general conditions are of greater exposure and low preservation of stratigraphic deposits in comparison to other loci in the Arroyo Verde locality (work in preparation) (Figure 6). The particular blowout studied here presents higher frequencies of pieces with advanced stages (2 and 3) of corrasion.

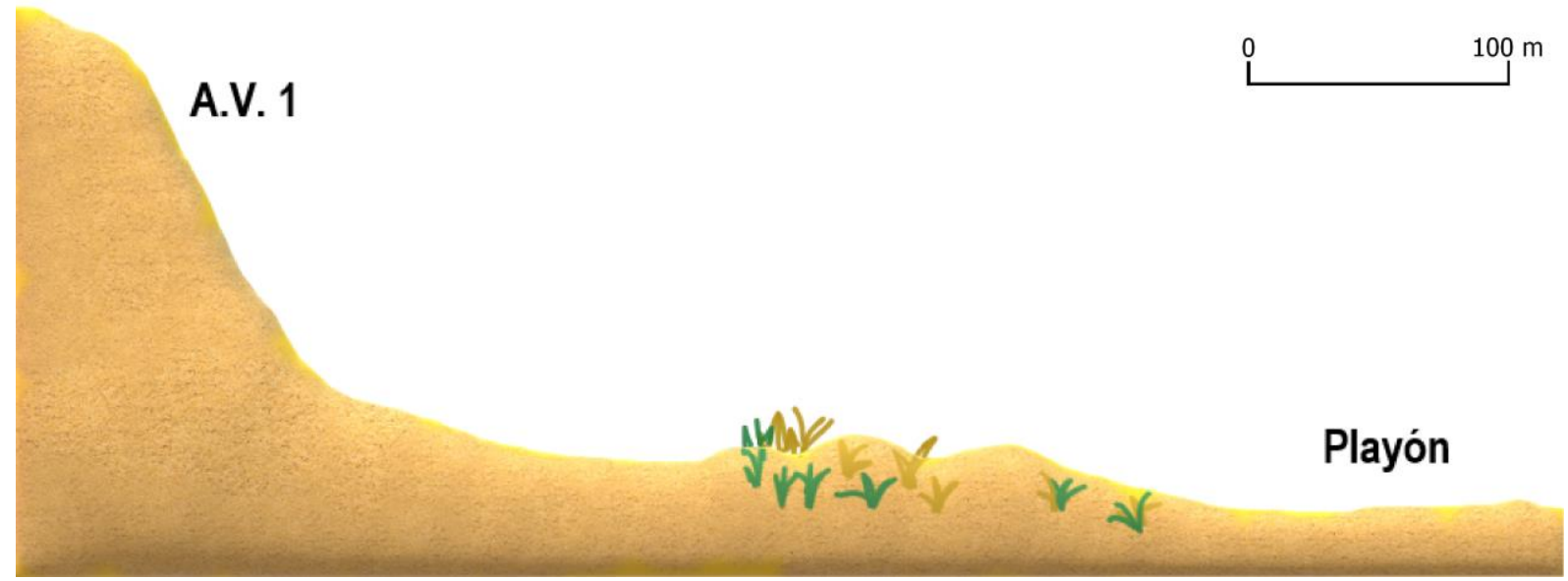

Figure 6. Diagram of Arroyo Verde locality and the spatial relationship between the Arroyo Verde 1 (Gómez Otero 2006) and Playón locus. 
The statistical model generated suggests that the occurrence of more or less stable conditions in this locus is related to the relative altitude. The gravitational processes allow the movement of items down on the dune slope and their incorporation towards the centre of the blowout that acts as a topographic trap. The application of decision trees allowed us to establish thresholds from which to expect the occurrence of stable conditions at different relative heights within the same blowout basin. However, the statistical model obtained a low value of adjustment to predict stable conditions, which suggests high variability and local dynamics. The pieces that registered advanced stages of corrasion are distributed in the lower area, whereas those pieces with less corrasion are located in higher sectors, on the slopes and edges of the sand dune. Therefore, this model cannot be extrapolated to other locations. We must adjust these predictive models to the scale that each case requires.

The results obtained from the distributional study of alterations do not offer a clear trend. This locus exhibits good preservation of small particles, but without spatial fidelity, that is to say, artefact distribution does not directly reflect knapping and other activities (Bertran et al. 2012; Borrazzo 2016). In previous work in the area, a deposit of small particles was recorded and interpreted as a by-product of wind action (Carranza 2017). So, these small particles could be part of the recently exposed archaeological contexts of the locus as well as items selectively removed from larger lithic assemblages.

Although there is still no clear chronology for human occupation at the Arroyo Verde locality, the date of 5,500 ${ }^{14} \mathrm{C}$ yr BP obtained from an aeolian deposit on a marine terrace provides a maximum date for the availability of this space for its occupation (Favier Dubois $e t$ al. 2017). The high density of the archaeological remains and the presence of site furniture at Arroyo Verde suggest that this locality was redundantly occupied, possibly due to the availability of resources. Other nearby locations, such as Punta Odriozola and Punta Pórfido, exhibit similar conditions. The expedient technology identified in this locus corresponds to what has been recorded in other localities of the region and is linked to the immediate acquisition of the required lithic resources (coastal lithic sources) (Alberti et al. 2015; Borella et al. 2015). Therefore, Arroyo Verde is a spot with attractive resources (e.g., fresh water, shelter and coastal fauna) for a semi-arid and rocky coast. Further studies will delve into the role of Arroyo Verde in coastal human occupations of northern Patagonia and provide additional data on the preservation of the archaeological record within the coast of the San Matias Gulf.

\section{Conclusions}

This paper aimed at understanding the surface lithic scatters recorded in a coastal dune context of the San Matías Gulf (Northern Patagonia, Argentina). We approached the formation processes in Arroyo Verde locality from a taphonomic perspective based on both environmental information and technological characterisation. The way lithic items move within the dune context and the different alteration rates provide new insights on the history of the local and regional archaeological record within this coastal environment. The next step will be to perform experimental studies to obtain detailed data on the dynamics observed in the dune contexts in terms of the rate of deflation, its effects on the distribution by weight and the intensity of corrasion of the artefacts. It remains necessary to compare and integrate the information obtained at Playón with that generated for other loci in the area, such as Arroyo Verde 1. Jointly, they will provide further insights for reconstructing the history of the postdepositional life of lithic artefacts in a reoccupied area. 


\section{Acknowledgement}

This work was carried out within the framework of projects financed by CONICET. I want to thank Marcelo Cardillo, Karen Borrazzo and Luis Borrero whose contributions and corrections were of great value to carry out this work. To Nora Franco and Xavier MangadoLlach, the organizers of the 11th Session of the ISKM (Buenos Aires, Argentina). Finally, I want to thank the reviewers for their helpful comments that improved the final version of this paper.

\section{References}

Alberti, J., Cardillo, M., \& Favier Dubois, C. M. 2015, Fuentes de materias primas líticas en la costa del golfo San Matías (provincia de Río Negro, Argentina). Una síntesis regional. Intersecciones en Antropología - Volumen especial 2: 27-37. (in Spanish) ("Lithic raw materials sources in the coast of San Matías Gulf (Río Negro province, Argentina. A regional synthesis") doi:10.5354/0719-1472.2013.30619

Alberti, J. \& Carranza, E. 2014, Primera caracterización de los conjuntos líticos provenientes de depósitos de tipo conchero en la costa del golfo San Matías (Río Negro, Argentina). La Zaranda de Ideas. Revista de Jóvenes Investigadores en Arqueología, 10(1): 47-64. (in Spanish) ("First characterization of lithic assemblages from shell middens located in San Matías Gulf coast (Río Negro province, Argentina") doi:10.31048/1852.4826.v9.n2.14430

Aschero, C. (1975), Ensayo para una clasificación morfológica de artefactos líticos aplicada a estudios tipológicos comparativos. Informe presentado al CONICET. MS., Buenos Aires, 113 p. (in Spanish) ("Reviewing typological issues regarding bifacial artifacts classification").

Aschero, C. (1983), Ensayo para una clasificación morfológica de artefactos líticos. Apéndice A y B. Cátedra de Ergología y Tecnología. Facultad de Filosofía y Letras, Universidad de Buenos Aires, Buenos Aires, 180 p. (in Spanish) ("Reviewing typological issues regarding bifacial artifacts classification") doi:10.20319/pijss.2017.32.20152033

Bailey, G. 2007, Time perspectives, palimpsests and the archaeology of time. Journal of Anthropological Archaeology, 26(2): 198-223. doi:10.1016/j.jaa.2006.08.002

Baker, C. M. 1978, The size effect: an explanation of variability in surface artifact assemblage content. American Antiquity, 43(2): 288-293. doi:10.2307/279254

Bertran, P., Lenoble A., Todisco D., Desrosiers, M. P., \& Sørensen, M. 2012, Particle size distribution of lithic assemblages and taphonomy of Palaeolithic sites. Journal of Archaeological Science, 39: 3148-3166. doi:10.1016/j.jas.2012.04.055.

Bird, E. C. 2011, Coastal Geomorphology: An Introduction. John Wiley \& Sons, Chichester, $405 \mathrm{p}$.

Bonomo, M., Scabuzzo, C., \& Leon, D. C. 2017, Cronología y dieta en la costa atlántica pampeana, Argentina. Intersecciones en Antropología, 14: 123-136. (in Spanish) ("Chronology and diet on the pampean atlantic coast, Argentina"). URL: http://ridaa.unicen.edu.ar/xmlui/handle/123456789/1202 
Borella, F., Mariano, C. \& Favier Dubois, C. 2007, Procesos tafonómicos en restos humanos en superficie en la localidad arqueológica de Bajo de la Quinta, golfo San Matías (Río Negro). In: Arqueología de Fuego-Patagonia. Levantando piedras, desenterrando huesos... y develando arcanos (Morello, F., Martinic, M., Prieto, A. \& Bahamonde, G., Eds.), CEQUA, Punta Arenas: p. 403-410. (in Spanish) ("Taphonomic processes in surface human remains in the archaeological site of Bajo de la Quinta, San Matías Gulf (Río Negro)") doi:10.4067/s0718-22442010000100008

Borella, F., Cardillo, M., Favier Dubois, C. \& Alberti, J. 2015, Nuevas investigaciones arqueológicas entre Punta Pórfido y Punta Odriozola: implicancias para el entendimiento de la dinámica de las ocupaciones humanas en la costa oeste del golfo San Matías (Río Negro). Relaciones de la Sociedad Argentina de Antropología, 40(1): 233-252. (in Spanish) ("New archaeological investigations between Punta Porfido and Punta Odriozola: implications for the understanding of the dynamics of human occupations on the west coast of the San Matías Gulf (Río Negro)") doi:10.4067/s071822442010000100008

Borrazzo, K. 2006, Tafonomía lítica en dunas: una propuesta para el análisis de los artefactos líticos. Intersecciones en Antropología, 7: 247-261. (in Spanish) ("Lithic taphonomy in dunes: a proposal for the lithic artefacts analysis")

URL: http://www.scielo.org.ar/scielo.php?script=sci_abstract\&pid=S1850373X2006000100018

Borrazzo, K. 2013, Tafonomía lítica y modelo de la dinámica eololacustre del norte de la Bahía San Sebastián (Tierra del Fuego, Argentina). Comechingonia. Revista de Arqueología, 17: 149-169. (in Spanish) ("Lithic taphonomy and a model of aeolianlacustrine dynamic in northern San Sebastian bay (Tierra del Fuego, Argentina)") doi:10.4067/s0718-22442005000200007

Borrazzo, K. 2016, Lithic taphonomy in desert environments: Contributions from FuegoPatagonia (Southern South America). Quaternary International, 422: 19-28. doi:10.1016/j.quaint.2015.12.012.

Borrazzo, K. 2018, Expanding the scope of Actualistic Taphonomy in Archaeological Research. In: Actualistic Taphonomy in South America (Martínez, S., Rojas, A., Verde, M. \& Cabrera, F., Eds.), Springer, New York: p. 2-38. doi:10.1007/978-3-030-20625-3

Borrazzo, K., \& Borrero, L. A. 2015, Taphonomic and archaeological perspectives from northern Tierra del Fuego, Argentina. Quaternary international, 373: 96-103. doi:10.1016/j.quaint.2014.09.004

Borrero, L.A. 2001, Regional taphonomy. Background noise and the integrity of the archaeological record. In: Ethnoarchaeology of Andean South America. Contributions to archaeological method and theory (Kuznar, L.A., Ed.), International Monographs in Prehistory, Ann Arbor: p. 243-254. doi:10.2307/971747

Borrero, L. A. 2007, Longitudinal Taphonomic Studies in Tierra del Fuego, Argentina. In: Taphonomy and Zooarchaeology in Argentina (Gutiérrez, M., Miotti, L., Barrientos, G., Mengoni Goñalons G., \& Salemme, M., Eds.), BAR International Series Vol. 1601. Archaeopress, Oxford: p. 219-233.

Breed, C., McCauley, J. \& Whitney, E. 1997, Wind Erosion Forms. In: Arid Zone Geomorphology (Thomas, D. S. G., Ed.), Wiley, London: p. 284-307. doi:10.1002/9780470710777.ch24 
Bullard, J. E. 2006, Arid Geomorphology. Progress in Physical Geography, 30(4): 542-552.

Butzer, K. W. 2004, Coastal eolian sands, paleosols, and Pleistocene geoarchaeology of the Southwestern Cape, South Africa. Journal of Archaeological Science, 31(12): 17431781. doi:10.1016/j.jas.2004.05.005

Cabrera, A.L. \& Willink, A. 1973, Biogeografía de América Latina. Monografía 13. Serie de Biología. Secretaría General de la Organización de los Estados Americanos, Washington D.C., 120 p. (in Spanish)("Biogeography of Latin America")

Cameron, D., White, P., Lampert, R. \& Florek, S. 1990, Blowing in the Wind. Site Destruction and Site Creation at Hawker Lagoon, South Australia. Australian Archaeology, 30: 58-69. doi:10.1080/03122417.1990.11681367

Camuffo, D. 1995, Physical Weathering of Stones. The Science of the Total Environment, 167: 4-14. doi:10.1016/0048-9697(95)04565-I

Carranza, E. 2017, Análisis tafonómico de conjuntos líticos de superficie en la costa norte del golfo San Matías (Rio Negro, Argentina). Intersecciones en Antropología, 18(1): 91101. (in Spanish) ("Taphonomic analysis of surface lithic assemblages from the northern coast of Gulf San Matías (Río Negro, Argentina)") doi:10.31048/1852.4826.v9.n2.14430

Cruz, I., Ercolano, B., Mastrángelo, D. C., Caracotche, M. S., \& Lemaire, C. R. 2015, Tafonomía y procesos de formación en P96 (Punta Entrada, Santa Cruz, Argentina). Cuadernos del Instituto Nacional de Antropología y Pensamiento Latinoamericano, 24(1): 96-115. (in Spanish) ("Taphonomy and training processes in P96 (Punta Entrada, Santa Cruz, Argentina)”) doi:10.5354/0719-1472.2014.36257

Davies, B., Holdaway, S. J., \& Fanning, P. C. 2016, Modelling the palimpsest: an exploratory agent-based model of surface archaeological deposit formation in a fluvial arid Australian landscape. The Holocene, 26(3), 450-463. doi:10.1177/0959683615609754

Dorn, R. 2009, Desert Rock Coatings. In: Geomorphology of Desert Environments (Parsons, A. \& Abrahams, A., Eds.) Springer, New York: p. 153-186. doi:10.1007/978-1-40205719-9

Fanning, P. \& Holdaway, S. 2001, Stone artifact scatters in western NSW, Australia: Geomorphic controls on artifact size and distribution. Geoarchaeology: An International Journal, 16(6): 667-686. doi:10.1002/gea.1015

Fanning, P. C., Holdaway, S. J., Rhodes, E. J., \& Bryant, T. G. 2009, The surface archaeological record in arid Australia: geomorphic controls on preservation, exposure, and visibility. Geoarchaeology: An International Journal, 24(2): 121-146. doi:10.1002/gea.20259

Favier Dubois, C., Borella, F., Manzi, L., Cardillo, M., Lanzellotti, S., Scartascini, F., Mariano, C. \& Borges Vaz, E. 2008, Aproximación regional al registro arqueológico de la costa rionegrina. In: Arqueología de la Costa Patagónica. Perspectivas para la conservación (Cruz, I. \& Caracotche, S. Eds.) Universidad Nacional de la Patagonia Austral, Río Gallegos: p. 50-68. (in Spanish) ("Regional approach to the archaeological record of the Río Negro coast”) doi:10.17227/01234870.41folios51.68 
Favier Dubois, C. \& Borella, F. 2007, Consideraciones acerca de los procesos de formación de concheros en la costa norte del Golfo San Matías (Río Negro, Argentina). Cazadores recolectores del Cono Sur, 2: 151-165. (in Spanish) ("Considerations about the processes of shellmidden formation in the northern coast of the San Matías Gulf") doi:10.4067/s0718-22442009000200008

Favier Dubois, C. \& Borella, F. 2011, Contrastes en la costa del golfo: una aproximación al estudio del uso humano del litoral rionegrino en el pasado. In: Arqueología de pescadores y marisqueadores en Nordpatagonia. Descifrando un registro de más de 6000 años (Borella, F. \& Cardillo, M., Eds.), Dunken, Buenos Aires: p. 13-42. (in Spanish) ("Differences in the coast of the Gulf: an approach to the study of the human use of the Río Negro province coast") doi:10.22305/ict-unpa.v2i3.59

Favier Dubois, C. \& Kokot, R. R. 2011, Changing scenarios in Bajo de la Quinta (San Matías Gulf, Northern Patagonia, Argentina): impact of geomorphologic processes in subsistence and human use of coastal hábitats. Quaternary International, 245(1): 103110. doi:10.1016/j.quaint.2011.03.051

Favier Dubois, C., Kokot, R., Scartascini, F., \& Borella, F. 2016, Una perspectiva geoarqueológica del registro de ocupaciones humanas en el Golfo San Matías (Río Negro, Argentina). Intersecciones en Antropología, 17: 47-59. (in Spanish) (“A geoarchaeological perspective of the registry of human occupations in the San Matías Gulf (Río Negro, Argentina)").

URL: http://www.scielo.org.ar/scielo.php?script=sci_arttext\&pid=S1850373X2016000400005

Favier Dubois, C., Borella, F. \& Cardillo, M. 2017, Cronologías de ocupación en la costa oeste del golfo San Matías (Río Negro): factores geomorfológicos involucrados. In: $X$ Jornadas de Arqueología de la Patagonia: libro de resúmenes (Gómez Otero, J., Ed.), Instituto de Diversidad y Evolución Austral, Puerto Madryn: p. 34. (In Spanish) ("Occupational chronologies on the west coast of the San Matías Gulf (Río Negro): geomorphological factors involved”) doi:10.5354/0719-1472.2013.30619

Gómez Otero, J. 2006, Dieta, uso del espacio y evolución en poblaciones cazadorasrecolectoras de la costa centro-septentrional de Patagonia durante el Holoceno medio y tardío. Doctoral thesis. Facultad de Filosofía y Letras, Universidad de Buenos Aires, Buenos Aires, 244 p. (in Spanish) ("Diet, use of space and evolution in hunter-gatherer populations of the central-northern coast of Patagonia during the Middle and Late Holocene") doi:10.20319/pijss.2017.32.20152033

Gifford, D. P. 1981, Taphonomy and paleoecology: a critical review of archaeology's sister disciplines. In: Advances in archaeological method and theory (Schiffer, M.B., Ed.), Academic Press, Arizona: p. 365-438. doi:10.1016/b978-0-12-003104-7.50013-2

González Díaz, E. \& Malagnino, E. 1984, Geomorfología de la provincia de Río Negro. In: Actas del IX Congreso Geológico Argentino. San Carlos de Bariloche: 7-149. (in Spanish) ("Geomorphology of the province of Río Negro.") URL: http://catalogosuba.sisbi.uba.ar/vufind/Record/201603080902036529

Lancaster, J. 1986, Wind Action on Stone Artifacts: an Experiment in Site Modification. News and Short Contributions. Journal of Field Archaeology, 13(3): 351-364. doi:10.1179/jfa.1986.13.3.351

Lancaster, N. 1998, Arid geomorphology. Progress in Physical Geography, 20(1): 551-557. doi:97-103.10.1177/030913339802200408 
Leonardt, S., Scheinsohn, V., Rizzo, F., \& Tchilinguirián, P. 2016, The memory of the landscape: Surface archaeological distributions in the Genoa Valley (Argentinean Patagonia). Quaternary International, 422: 5-18. doi:10.1016/j.quaint.2015.11.131

Livingstone, I. \& Warren, A. 1996, Aeolian Geomorphology: an Introduction. Longman, Harlow, 204 p. URL: http://nectar.northampton.ac.uk/5691/

Manzi, L., Borella, F. \& Cardillo, M. 2011 Distribuciones artefactuales: una aproximación a la estructura espacial del registro arqueológico del litoral atlántico rionegrino. In: Arqueología de pescadores y marisqueadores en Nordpatagonia. Descifrando un registro de más de 6000 años (Borella, F. \& Cardillo, M., Eds.), Editorial Dunken, Buenos Aires: p. 43-66. (in Spanish) (“Artefactual distributions: an approximation to spatial structure of the archaeological record of Rio Negro Atlantic coast") doi:10.22305/ict-unpa.v2i3.59

Manzi, L., Favier Dubois, C. \& Borella, F. 2009. Identificación de agentes perturbadores y estrategias tendientes a la conservación del patrimonio arqueológico en la costa del Golfo de San Matías, provincia de Río Negro. Intersecciones en Antropología, 10: 3-16. (in Spanish) ("Identification of disruptive agents and strategies for the conservation of archaeological heritage on the coast of the San Matías Gulf, province of Río Negro") doi:10.22305/ict-unpa.v2i3.59

Mayer, J. H. 2002, Evaluating natural site formation processes in eolian dune sands: A case study from the Krmpotich Folsom Site, Killpecker Dunes, Wyoming. Journal of Archaeological Science, 29: 1199-1211. doi:10.1006/jasc.2001.0803

Phillips, D.N., Neth, H., Woike, J.K. \& Gaissmaier W. 2017, FFTrees: A toolbox to create, visualize, and evaluate fast-and-frugal decision trees. Judgment and Decision Making, 12(4): 344-368. doi:10.1002/047001332X.ch10

Rick, T. C. 2002, Eolian processes, ground cover, and the archaeology of coastal dunes: A taphonomic case study from San Miguel Island, California, USA. Geoarchaeology: An International Journal, 17(8): 811-833. doi:10.1002/gea.10047

Servicio de Hidrografía Naval (2009), Tablas de Marea. (pamphlet), Servicio de Hidrografía Naval, Armada Argentina. p. 643. (in Spanish) ("Tide Table")

Servicio Meteorológico Nacional (2014), Estadística climatológica de San Antonio Oeste del período 2001-2010. (pamphlet), Servicio Meteorológico Nacional. Centro de información meteorológica. Secretaría de Ciencia, Tecnología y Producción para la Defensa. Ministerio de Defensa. Exp. N 143.736. Buenos Aires, 20 p. (in Spanish) ("Climatological statistics of San Antonio Oeste from 2001-2010")

Song, Y. Y., \& Ying, L. U. 2015, Decision tree methods: applications for classification and prediction. Shanghai Archives of Psychiatry, 27(2): 130-135. doi:10.11919/j.issn.10020829.215044 .

Waters, M. R. 1992, Principles of Geoarchaeology: A North American perspective. University of Arizona Press, Arizona, 398 p.

Weitzel C., Borrazzo, K., Ceraso, A. \& Balirán, C. 2014, Trampling fragmentation potential of lithic artefacts: an experimental approach. Intersecciones en Antropología - Special Issue 1: 97-110. URL: http://www.scielo.org.ar/scielo.php?pid=S1850373X2014000300009\&script=sci_arttext\&tlng=pt 